\title{
A novel sensitive colorimetric determination of catecholamine drug in dosage form via oxidative coupling reaction with MBTH and potassium ferricyanide
}

\author{
Safwan Ashour ${ }^{\mathrm{a}, \mathrm{b}^{*}}$ \\ ${ }^{a}$ Department of Materials Science, Faculty of Engineering, University of Gaziantep, Gaziantep, Turkey \\ ${ }^{b}$ Department of Chemistry, Faculty of Sciences, University of Aleppo, Aleppo, Syria \\ *Corresponding author: sashour@gantep.edu.tr
}

\begin{abstract}
A new and direct colorimetric method has been established for the determination of catecholamine (methyldopa, MD) in both pure form and in pharmaceutical formulations. The method is based on the oxidative coupling reaction of MD with 3-methyl-2-benzothiazolinone hydrazone hydrochloride monohydrate (MBTH) and potassium ferricyanide at $\mathrm{pH} 10.4$ in aqueous medium to form an orange product that has a maximum absorption at $460 \mathrm{~nm}$. Beer's law plot showed good correlation in the concentration range of $1.0-56.0 \mu \mathrm{g} \mathrm{mL}^{-1}$, with detection limit of $0.303 \mu \mathrm{g} \mathrm{mL}^{-1}$. Molar absorptivity for the above method was found to be $6.56 \times 10^{3} \mathrm{~L} \mathrm{~mol}^{-1} \mathrm{~cm}^{-1}$. All the measurements were carried out at $25 \pm 1.0{ }^{\circ} \mathrm{C}$, the formation constant $\left(\log K_{f}\right)$ value of colored species is 9.48 and the standard free energy $\left(\Delta G^{\ddagger}\right)$ is $-54.09 \mathrm{KJ}^{\mathrm{mol}}{ }^{-1}$. This method was applied successfully to determination of MD in tablets and the results were compared with the USP method. Common excipients used as additives in tablets do not interfere in the proposed method. The method is accurate, precise and highly reproducible, while being simple, cheap and less time consuming and hence can be suitably applied for routine analysis of MD in bulk and dosage forms.
\end{abstract}

Key words: Methyldopa, MBTH, colorimetry, pharmaceutical dosage forms.

https://doi.org/10.22456/2527-2616.113058

\section{Introduction}

Methyldopa (MD), chemically known as $\alpha$-methyl-3,4dihydroxyphenylalanine, is a catechol derivative (catecholamine) broadly prescribed to manage mild to moderate hypertension. In this context, methyldopa intrinsic chemical features may be explored through myriad analytical principles in order to optimize its detection. Amongst these features, the hydroxyl groups present in the molecule may undergo oxidation [1]. The official method reported in USP [2] describes a non-aqueous titration for the assay of methyldopa. Several analytical techniques have been cited in the literature for determination of methyldopa, either alone or in combination with other drugs, in bulk form, pharmaceutical formulations or biological fluids due to the wide use of this drug in numerous cardiac and circulatory diseases. These analytical methods include titrim etry $[3,4]$, voltammetry [5-9], potentimetry $[10,11]$, chemiluminescence [12,13], amperometry [14], capillary electrophoresis [15], HPLC with ultraviolet detector [16,7], HPLC with fluorescence detector [18], HPLC with electrochemical detection [19] and HPLC-electrospray tandem mass spectrometry (LC/MS/MS) [20]. Nuclear magnetic resonance (NMR) method for serum and pharmaceuticals was also reported [21]. However, massselective detection and $\mathrm{nmr}$ are cost intensive and often not available for routine analysis. Some of these methods described above have disadvantages such as not simple for direct application to a large scale routine analysis, low sensitivity, long analysis times, and/or require expensive or sophisticated instruments. Also, titrimetric methods, which were indirect titration and based on reduction reactions and present disadvantages such as interferences of unsaturated organic compounds.
Many spectrophotometric procedures have been proposed for the estimation of MD in pharmaceutical preparations including difference UV-spectrophotometric assay in the presence of germanium dioxide at $292 \mathrm{~nm}$ [22], Flowinjection spectrophotometry [23-26], fluorimetry [27,28], kinetic spectrophotometry [29-31] and extractive spectrophotometry [32,33]. Moreover, the colorimetric method was the most widespread for estimation of MD in dosage form using $\mathrm{I}_{2}$ solution with acetate buffer of $\mathrm{pH} 4.7$ [4], 2-aminothiazole in alkaline medium [25], thiosemicarbazide in presence of ferric nitrate [26], $\mathrm{NH}_{4} \mathrm{VO}_{3}$ in the presence $\mathrm{H}_{3} \mathrm{PO}_{4}$ [34], $\left(\mathrm{NH}_{4}\right)_{6} \mathrm{Mo}_{7} \mathrm{O}_{24} .4 \mathrm{H}_{2} \mathrm{O}$ solution in $\mathrm{H}_{2} \mathrm{SO}_{4}$ [35], $\mathrm{Fe}(\mathrm{III})$-ophenanthroline [36], barbituric acid [37], isoniazid in presence of $N$ bromosuccinamide [38], diazotised sulphanilamide in the presence of molybdate [39], periodate in $\mathrm{H}_{2} \mathrm{SO}_{4}$ and determination of unreacted periodate by adding methylene blue and KI [40], iron (III) in the presence of 1,10 phenanthroline and 2,2'-bipyridyl [41], p-nitroaniline in the presence of molybdate ions in acidic medium [42], $\mathrm{Ce}$ (IV) nitrate solution in $\mathrm{H}_{2} \mathrm{SO}_{4}$ [43], bromothymol blue in alkaline medium [44], sodium nitrite in an acid medium and further reacting the resultant nitroso derivative with sodium hydroxide [45], 2,2-diphenyil-picrylhydrazyl [46], 2,6dichloroquinone-4-chlorimide in acetate buffer and in water and ethanol solvents [47] and p-phenylenediamine in phosphate buffer at pH 7.4 [48]. 3-methylbenzothiazolin-2one hydrazone hydrochloride (MBTH) was used with $\left(\mathrm{NH}_{4}\right)_{2} \mathrm{SO}_{4} \cdot \mathrm{Ce}\left(\mathrm{SO}_{4}\right)_{2}$ in acetone or with $\mathrm{K}_{2} \mathrm{Cr}_{2} \mathrm{O}_{7}$ in methanol medium to determine MD. Beer's law was obeyed for 10 to $35 \mu \mathrm{g} \mathrm{mL}^{-1}$ and recoveries of methyldopa were 98.7 to $101 \%$ [49]. Most of the spectrophotometric methods reported present some disadvantages such as require long waiting times [4,22,35-37,43], heating step [32,36,37,43] for the reaction development, instability of the colored 
product at higher temperature $[38,48]$, complex procedure $[32,40,41,45]$, require non-aqueous media $[10,32,33,47,49]$ or poor detection limit $[34,48]$.

In this work, a validated colorimetric procedure for the determination of methyldopa in bulk and dosage form by the application of oxidative coupling reaction is described. This procedure is new, rapid, inexpensive, does not involve any pretreatment procedure or heating steps and has smaller sample consumption. The main advantage of this method is more sensitive in relation to the other published colorimetric methods.

\section{Experimental}

\section{Instrumentation}

A Shimadzu UV-1650PC spectrophotometer (Japan) with $1.0 \mathrm{~cm}$ quartz cells was used for all absorbance measurements. Spectra were automatically obtained by Shimadzu UV-1650PC system software. $\mathrm{pH}$ measurements and automatic potentiometric titration were made with Metrohm Compact Titrator Model 794 Basic Titrino (Switzerland) with glass $\mathrm{pH}$ electrode.

\section{Materials and chemicals}

Methyldopa, working standard, was obtained from S.A. Infinity (India). Its purity was found to be $99.5 \%$ according to the pharmacopeial method. Aldomet (Algorithm, Lebanone) and Dopegyt (Bahri Labs., Syria) tablets were purchased from local market, labeled to contain $250 \mathrm{mg}$ of methyldopa per tablet. All chemicals used were of analytical grade. 3-methyl-2-benzothiazolinone hydrazone hydrochloride monohydrate (MBTH, Fluka) solution $(0.01$ $\mathrm{M}), \mathrm{K}_{3}\left[\mathrm{Fe}(\mathrm{CN})_{6}\right](\mathrm{BDH})$ solution $(0.01 \mathrm{M})$ and $\mathrm{Na}_{2} \mathrm{CO}_{3}$ solution $(0.1 \mathrm{M})$ were prepared in bidistilled water. All the solutions were stable for one week at least when stored in the dark at $2-8{ }^{\circ} \mathrm{C}$.

\section{Standard drug solutions}

Standard stock solution of MD $\left(1.0 \mathrm{mg} \mathrm{mL}^{-1}\right)$ was prepared by dissolving the appropriate weight of MD in $100 \mathrm{~mL}$ bidistilled water. Working standard solutions were then prepared by suitable dilution of the stock standard solution with bidistilled water.

\section{Reaction stoichiometry}

Job's method of continuous variation and molar ratio method were applied to study the stoichiometric ratio of the complex formed [50]. $1 \times 10^{-3} \mathrm{M}$ of $\mathrm{MD}$ and $1 \times 10^{-2} \mathrm{M}$ of MBTH solutions were used. In the molar ratio method a constant volume of MD solution was treated with varying volume of MBTH to obtain a ratio for the complex $(0: 1$, $0.1: 0.9,0.2: 0.8, \ldots, 1: 0)$, while in Job's method, a series of MD-MBTH solutions was prepared to obtain a ratio for the complex $(0: 1,0.1: 0.9,0.2: 0.8, \ldots, 1: 0)$ where $\mathrm{C}_{\mathrm{MD}}+\mathrm{C}_{\mathrm{MBTH}}$ $=2.0 \times 10^{-3} \mathrm{M}$. The absorbance of the resulting solutions was measured at $\lambda_{\max }$ against the reagent blanks treated similarly.

\section{Validation of the proposed method}

The methods were validated in accordance with the International Conference on Harmonization (ICH) guidelines [51].

\section{Linearity}

To establish linearity of the proposed method, five separate series of solutions of MD $\left(1.0-56.0 \mu \mathrm{g} \mathrm{mL}^{-1}\right)$ were prepared from the stock standard solution and analyzed. Aliquots of $0.01-0.56 \mathrm{~mL}$ solution of MD $\left(1.0 \mathrm{mg} \mathrm{mL}^{-1}\right)$ were piptted into a series of $10 \mathrm{~mL}$ calibrated volumetric flasks. In each flask, $0.6 \mathrm{~mL}$ of $0.01 \mathrm{M} \mathrm{MBTH}$ was added and kept aside for $5 \mathrm{~min} .2 .0 \mathrm{~mL}$ of $0.01 \mathrm{M} \mathrm{K}_{3}\left[\mathrm{Fe}(\mathrm{CN})_{6}\right]$ and $0.2 \mathrm{~mL}$ of 0.1 $\mathrm{M} \mathrm{Na} \mathrm{CO}_{3}$ were added. The volume was made up to the mark with water at $25 \pm 1.0{ }^{\circ} \mathrm{C}$. The contents of each flask were mixed well and the absorbance was measured at 460 $\mathrm{nm}$ against a similar reagent blank within the stability period of 60 min after color development. The calibration graph of absorbance versus concentration of MD was constructed and described by the regression equation, $\mathrm{A}=m \mathrm{C}+b$ (where $\mathrm{A}$ is the absorbance of a $1 \mathrm{~cm}$ layer, $m$ is the slope, $b$ is the intercept and $\mathrm{C}$ is the concentration of $\mathrm{MD}$ in $\mu \mathrm{g} \mathrm{mL}^{-1}$ ) obtained by least-squares method [52].

\section{Sensitivity}

The sensitivity of the method was determined on the limit of detection (LOD) and limit of quantification (LOQ). LOD and LOQ of the drug assay were determined experimentally after getting the regression equation. LOD was expressed as the concentration of drug that generated a response to three times of the signal to-noise $(\mathrm{S} / \mathrm{N})$ ratio $\mathrm{LOD}=3.3 \times S_{\mathrm{b}} / m$ and LOQ was 10 times of the $\mathrm{S} / \mathrm{N}$ ratio $\mathrm{LOQ}=10 \times S_{\mathrm{b}} / m$ (where $S_{\mathrm{b}}$ is the standard deviation of the intercept and $m$ is the slope of the calibration curve) [53].

\section{Precision}

Repeatability was determined by using different levels of drug concentrations (same concentration levels taken in accuracy study), prepared from independent stock solutions and analyzed $(n=6)$ (Table 2$)$. The percent relative standard deviation (\%RSD) of the predicted concentrations from the regression equation was taken as precision (Table $3)$. Precision studies were also carried out using the real samples of MD tablets in a similar way to standard solution to prove the useful of method.

\section{Accuracy}

To determine the accuracy of the proposed method, different levels of drug concentrations were prepared from independent stock solutions and analyzed $(n=6)$. Accuracy was assessed as the percentage relative error and mean 
percentage recovery. The percentage relative error calculated using the following equation:

$\operatorname{Er} \%=\left[\frac{\text { founded }- \text { added }}{\text { added }}\right] \times 100$

\section{Selectivity}

The selectivity of the method was ascertained by analyzing standard drug in the presence of common excipients such as lactose, magnesium stearate, cellulose and silicon dioxide. For this purpose, a powder blend using typical tablet excipients was prepared along with the drug and then analyzed.

\section{Robustness}

The robustness of an analytical procedure is a measure of its capacity to remain unaffected by small, but deliberate variations in method parameters and provides an indication of its reliability during normal usage. These condition changes included the concentration of the reagents in the reaction, measurement time and temperature.

\section{Procedure for formulations}

Twenty tablets containing MD were weighed and pulverized. Amount of the powder equivalent to $50 \mathrm{mg}$ of MD was dissolved in a $25 \mathrm{~mL}$ of methanol and mixed for about 5 minutes and then filtered through Whatman filter paper number 40 . The methanol was evaporated to about the dryness. The remaining portion of solution was diluted in a $50 \mathrm{~mL}$ volumetric flask to the volume with double distilled water to achieve a concentration of $1 \mathrm{mg} \mathrm{mL}^{-1}$. The general procedure was then followed in the concentration range mentioned above.

\section{Stability constant $\left(K_{f}\right)$ and the standard free energy $\left(\Delta G^{\circ}\right)$ of coloured species}

The stability constant $\left(K_{\mathrm{f}}\right)$ of the complex formed by MD with MBTH was determined by substituting the data of continuous variation in the equation (2) derived for calculating the stability constant spectrophotometricaly.

$$
K_{f}=\frac{A / A_{m}}{\left[1-\left(A / A_{\max }\right)\right]^{n+2} \cdot C_{M}(n)^{n}}
$$

where $A$ is the maximum observed absorbance and $A_{m}$ is the absorbance value when all the amount of drug is associated. $C_{M}$ is the mole concentration of drug at the maximum absorbance and $n$ is the combination ratio of the ion-pair considered [54].

The standard free energy of the reaction product is related to the association or the formation constant by the equation (3), which was used to calculate $\Delta G^{\mathrm{o}}$ [55]:

$\Delta G^{\circ}=-2.303 R T \log K$ where $\Delta G^{\circ}$ is the free energy change of the complex, $R$ is the gas constant $8.314 \mathrm{~J} \mathrm{k}^{-1} \mathrm{~mol}^{-1}, T$ is the temperature in Kelvin (k), $K$ is the formation constant of complex.

\section{Results and discussion}

\section{Absorption spectra}

In order to establish experimental conditions, the effect of various parameters such as volumes of reagents, waiting time, order of addition of reagents and the stability of colored oxidative coupling product were studied at room temperature. The applicability of MBTH in combination with various oxidizing agents such as $\mathrm{Fe}(\mathrm{III}), \mathrm{IO}_{4}^{-}$, $\left(\mathrm{NH}_{4}\right)_{2} \mathrm{~S}_{2} \mathrm{O}_{8}$ and $\mathrm{Fe}(\mathrm{CN})_{6}{ }^{3-}$ were examined. Preliminary investigations revealed that the cationic oxidant [Fe(III)] produced yellow color with MD and enhanced the final color. So, further investigations were carried out with anionic oxidants as they do not produce any color directly with $\mathrm{MD} . \mathrm{Fe}(\mathrm{CN})_{6}{ }^{3-}$ was found to be superior because of its sensitivity over $\mathrm{IO}_{4}^{-}$. Different buffers were used to determine the optimal $\mathrm{pH}$ for the reaction. $0.1 \mathrm{M} \mathrm{Na}_{2} \mathrm{CO}_{3}$ with $\mathrm{pH} 10.4$ gave the optimal $\mathrm{pH}$ required for the reaction. Of the different solvents tried, water was found to be the most suitable solvents. The color product was stable for further $60 \mathrm{~min}$ and was measured at $460 \mathrm{~nm}$ (Figure 1).

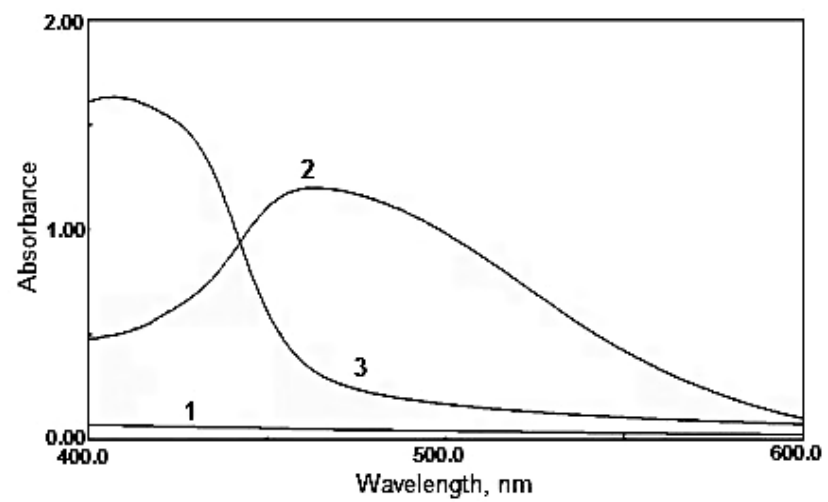

Figure 1. Absorption spectra of (1) $0.5 \mathrm{~mL}$ of $1 \mathrm{mg} \mathrm{mL} \mathrm{m}^{-1} \mathrm{MD}$ against distilled water, (2) $\mathrm{MD}\left(45 \mu \mathrm{g} \mathrm{mL}^{-1}\right)-\mathrm{MBTH}(0.6 \mathrm{~mL}$ of $\left.10^{-2} \mathrm{M}\right)$ in the presence of $\mathrm{Na}_{2} \mathrm{CO}_{3}(0.2 \mathrm{~mL}$ of $0.1 \mathrm{M})$ and ferricyanide $\left(2.0 \mathrm{~mL}\right.$ of $\left.10^{-2} \mathrm{M}\right)$ system against reagent blank (3) vs. distilled water.

\section{Optimization of reaction conditions}

In order to establish experimental conditions of the developed color product, the effect of various parameters such as temperature, order of addition of reagents, concentration of reagents, reaction time and the stability of product were studied.

\section{Effect of temperature and order of addition}

The laboratory temperature $\left(25 \pm 1.0^{\circ} \mathrm{C}\right)$ was found to be optimal for all the experiments. Addition of MD, MBTH, $\mathrm{Fe}(\mathrm{CN})_{6}{ }^{3-}$ and $\mathrm{Na}_{2} \mathrm{CO}_{3}$ in that order gave maximum absorbance. Altering this order of addition (i.e. MD + 
$\left.\mathrm{Fe}(\mathrm{CN})_{6}^{3-}+\mathrm{MBTH}+\mathrm{Na}_{2} \mathrm{CO}_{3}\right)$ resulted in decrease in absorbance.

\section{Effect of reaction time}

The effect of time on the reaction of MD with MBTH and $\mathrm{Fe}(\mathrm{CN})_{6}{ }^{3-}$ in the presence of $\mathrm{Na}_{2} \mathrm{CO}_{3}$ is studied at $\lambda_{\max }$ and laboratory ambient temperature $\left(25 \pm 1.0^{\circ} \mathrm{C}\right)$. The reaction went to completion within $5 \mathrm{~min}$ and the absorbance of the chromogen remains stable for $60 \mathrm{~min}$. Therefore, all measurements were carried out after 10 min of mixing of the reagents.

\section{Effect of reagent concentration}

The effect of MBTH, $\mathrm{Fe}(\mathrm{CN})_{6}{ }^{3-}$ and $\mathrm{Na}_{2} \mathrm{CO}_{3}$ concentrations were investigated. For maximum color development, solutions of $0.6 \mathrm{~mL}$ of $0.01 \mathrm{M} \mathrm{MBTH}, 2.0 \mathrm{~mL}$ of $0.01 \mathrm{M}$ $\mathrm{Fe}(\mathrm{CN})_{6}{ }^{3-}$ and $0.2 \mathrm{~mL}$ of $0.1 \mathrm{M} \mathrm{Na}_{2} \mathrm{CO}_{3} \mathrm{pH} 10.4$ were found to be optimal of $\mathrm{MD}$, since the absorbance was found to be maxima at the mentioned volumes, as shown in Figure 2.

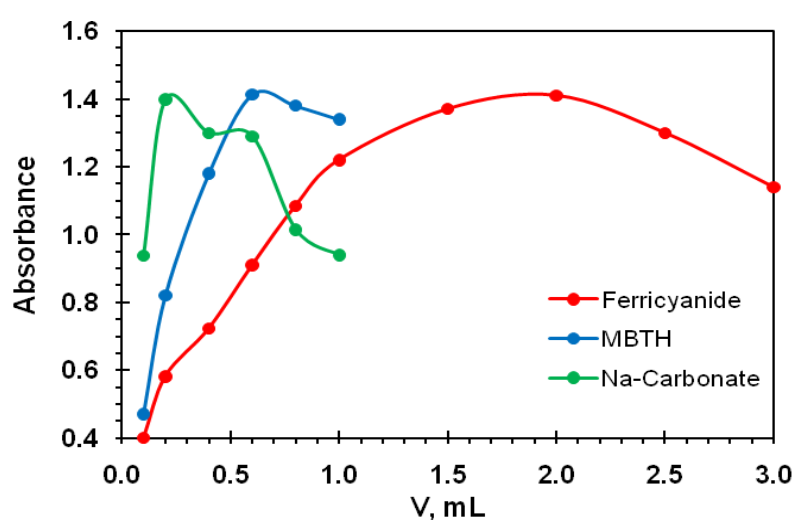

Figure 2. Effect of concentration of MBTH in the presence of 2.0 $\mathrm{mL}$ of $10^{-2} \mathrm{M} \mathrm{Fe}(\mathrm{CN}) 6^{3-}$ and $0.2 \mathrm{~mL}$ of $0.1 \mathrm{M} \mathrm{Na}_{2} \mathrm{CO}_{3} \mathrm{pH} 10.4$, $\mathrm{Fe}(\mathrm{CN}) 6^{3-}$ in the presence of $0.6 \mathrm{~mL}$ of $10^{-2} \mathrm{M} \mathrm{MBTH}$ and $0.2 \mathrm{~mL}$ of $0.1 \mathrm{M} \mathrm{Na}_{2} \mathrm{CO}_{3} \mathrm{pH} 10.4$ and $\mathrm{Na}_{2} \mathrm{CO}_{3} \mathrm{pH} 10.4$ in the presence of $0.6 \mathrm{~mL}$ of $10^{-2} \mathrm{M} \mathrm{MBTH}$ and $2.0 \mathrm{~mL}$ of $10^{-2} \mathrm{M} \mathrm{Fe}(\mathrm{CN}) 6^{3-}$ on the formation of colored oxidative coupling product MD-MBTH. $\mathrm{C}_{\mathrm{MD}}=50 \mu \mathrm{g} \mathrm{mL}^{-1}$.

\section{Stoichiometric Relationship}

The composition of MD-MBTH colored oxidative coupling product was determined by Job's method using equimolar solution. The plot reached maximum at a mole fraction of 0.33 and 0.5 , indicating the formation of $1: 2$ and $1: 1$ (MD:MBTH) colored product (Figure 3A). Also, the moleratio method showed the formation of $1: 1$ and $1: 2$ (MD:MBTH) colored product (Figure 3B).
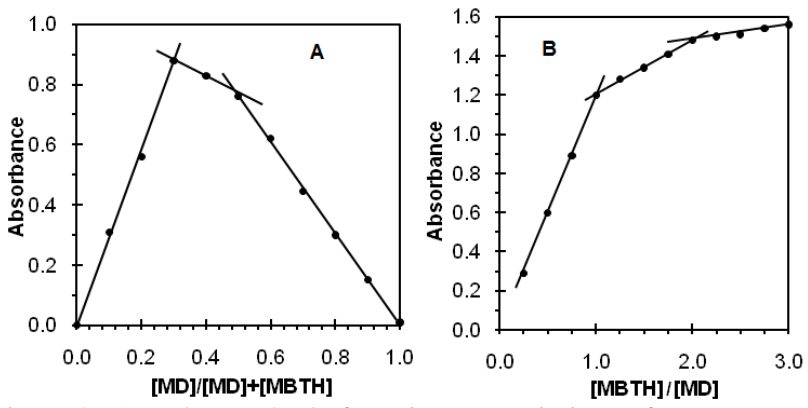

Figure 3. (A) Job's method of continuous variations of MD-MBTH product: $\mathrm{C}_{\mathrm{MD}}+\mathrm{C}_{\mathrm{MBTH}}=2.0 \times 10^{-3} \mathrm{M}$. (B) Mole-ratio method of MDMBTH product, $\mathrm{C}_{\mathrm{MD}}=5 \times 10^{-4} \mathrm{M}$ and $\mathrm{C}_{\mathrm{MBTH}}=125-1500 \mu \mathrm{M}$.

When treated with ferricyanide, MBTH undergoes oxidation with loss of proton from nitrogen atom, and yields $\mathrm{R}^{\prime}$ form or $\mathrm{R}^{\prime \prime}$ form. Also, MD is oxidized with loss of proton from the ring and coupling with the reagent $\mathrm{R}^{\prime}$, or oxidized from enolic to ketonic form and coupling with the reagent $\mathrm{R}$ " to form the colored oxidative coupling product, as shown in Figure 4.

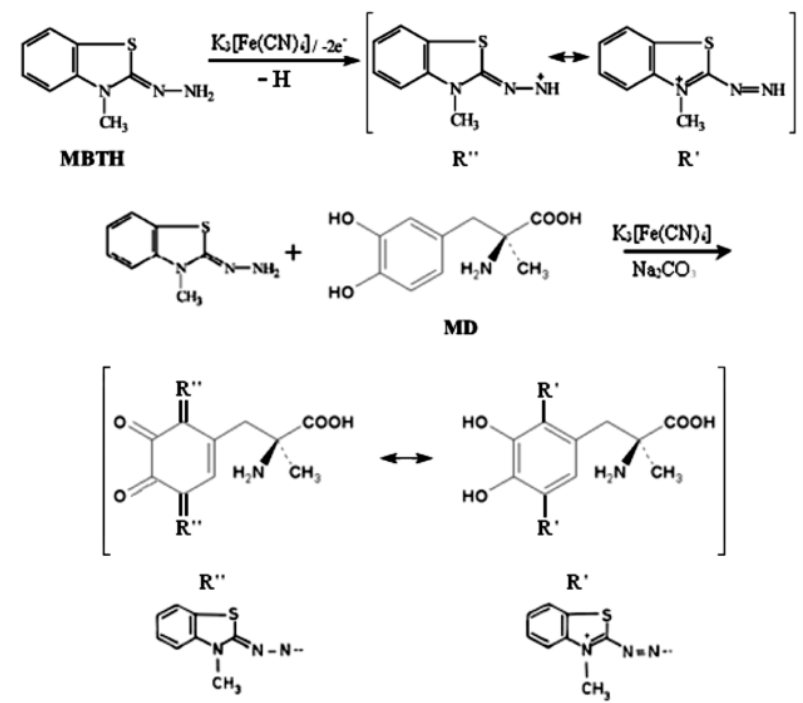

Figure 4. Structure of MD and its reaction product with MBTH in alkaline medium.

\section{The stability constant $\left(K_{f}\right)$ and the standard free energy $(\Delta G)$}

The stability constant $\left(K_{f}\right)$ value of MD complex with MBTH was calculated from the continuous variation data using equation (2) and is tabulated in Table 1 . The value of Gibbs free energy $\left(\Delta G^{\ddagger}\right)$ of activation of the reaction product was determined using the equation 3 , and its value was $-54.09 \mathrm{KJ} \mathrm{mol}^{-1}$. The negative value of the calculated free energy $\left(\Delta G^{\ddagger}\right)$ indicates the stability of the complex and its spontaneous formation. 
Table 1. Optical characteristics and regression parameters for MD by the proposed method.

\begin{tabular}{|l|l|}
\hline Parameter & MD \\
\hline$\lambda_{\max }(\mathrm{nm})$ & 460 \\
\hline Beer's law range $\left(\mu \mathrm{g} \mathrm{mL}^{-1}\right)$ & $1.0-56.0$ \\
\hline Molar absorptivity $\left(\mathrm{L} \mathrm{mol}^{-1} \mathrm{~cm}^{-1}\right)$ & $6.56 \times 10^{3}$ \\
\hline $\begin{array}{l}\text { Optimum photometric range } \\
\left.(\mu \mathrm{g} \mathrm{mL})^{-1}\right)\end{array}$ & $5.0-40.0$ \\
\hline $\begin{array}{l}\text { Logarithmic formation constant } \\
\left(\log K_{f}\right)\end{array}$ & $4.48(1: 1), 9.48(1: 2)$ \\
\hline $\mathrm{LOD}\left(\mu \mathrm{gL}^{-1}\right)$ & 0.303 \\
\hline $\mathrm{LOQ}\left(\mu \mathrm{g} \mathrm{\textrm {m } ^ { - 1 } )}\right.$ & 1.000 \\
\hline $\begin{array}{l}\text { Sandell's sensitivity }\left(\mu \mathrm{g} \mathrm{cm} \mathrm{cm}^{-2} \mathrm{per}\right. \\
0.001 \text { abs. unit) }\end{array}$ & 0.0329 \\
\hline Regression equation & \\
\hline Correlation coefficient, $r$ & $A=0.0274 C+0.0188$ \\
\hline
\end{tabular}

a With respect to $A=m C+b$, where $A$ is the absorbance and $C$ is the concentration $\left(\mu \mathrm{g} \mathrm{mL}^{-1}\right) . n=5$.

\section{Validation of the proposed method}

The validity of the method for analysis of MD in its pure state and in formulations was examined by analyzing the samples using the proposed procedure. The precision and accuracy of the method were tested by analyzing six replicates of MD. The low values of RSD\% indicate good precision and reproducibility of the method.

\section{Linearity, $L O D$ and $L O Q$}

In order to test whether the colored oxidative coupling product formed in the above method adhere to Beer's law, the absorbance at appropriate length of a set of solutions containing varying amounts of MD and specified amounts of reagents (as given in the recommended procedure) were recorded against the corresponding reagent blank. A linear relationship was found between the absorbance at $\lambda_{\max }$ and the concentration of MD in the range of $0.92-56.0 \mu \mathrm{g} \mathrm{mL}$ ${ }^{1}$, with LOD of $0.31 \mu \mathrm{g} \mathrm{mL}{ }^{-1}$ and LOQ of $0.74 \mu \mathrm{g} \mathrm{mL}^{-1}$. Regression analysis of the Beer's law plots reveals a good correlation $(r>0.999)$ and negligible intercept, as shown in Table 1. The high molar absorptivitie of the resulting colored oxidative coupling product indicates the high sensitivity of the method. Sandell's index represents the number of micrograms or nanograms of the determinant per millilitre of a solution having an absorbance of 0.001 for the cell path length of $1.0 \mathrm{~cm}$ and is a suitable parameter for expressing and comparing the sensitivity of developed spectrophotometric method.

\section{Intra- and interday accuracy and precision}

Repeatability was determined by using different levels of MD concentrations prepared from independent stock solutions and analyzed. Accuracy was assessed as the percentage relative error and mean percentage recovery. The percent relative standard deviation (RSD\%) of the predicted concentrations from the regression equation was taken as precision. Five different concentrations of MD were analyzed in six replicates on the same day (intraday precision) and on four consecutive days (interday precision), as shown in Table 2. Precision studies were also carried out using the real samples of MD tablets in a similar way to standard solution to prove the useful of method.

Table 2. Accuracy and precision of within and between run analysis for the determination of MD in bulk powder by the proposed method.

\begin{tabular}{|c|c|c|c|c|}
\hline $\begin{array}{c}\text { Amount taken } \\
\left(\boldsymbol{\mu} \mathbf{g} \mathbf{~ m L}_{\mathbf{~}}^{\mathbf{- 1}}\right)\end{array}$ & $\begin{array}{c}\text { Amount found } \\
\left(\boldsymbol{\mu} \mathbf{g} \mathbf{~ m L}^{-\mathbf{1}}\right)\end{array}$ & $\begin{array}{c}\text { RSD } \\
\mathbf{\%}\end{array}$ & $\begin{array}{c}\text { Recovery } \\
(\mathbf{\%})\end{array}$ & $\begin{array}{c}\mathbf{E r} \\
\mathbf{\%}\end{array}$ \\
\hline $\begin{array}{c}\text { Intra-day }(n=6) \\
1.00\end{array}$ & 1.02 & 0.92 & 102.00 & 2.00 \\
5.00 & 5.03 & 0.83 & 100.66 & 0.66 \\
15.00 & 15.04 & 0.67 & 100.60 & 0.60 \\
25.00 & 25.12 & 0.54 & 100.60 & 0.60 \\
40.00 & 40.21 & 0.41 & 100.55 & 0.55 \\
\hline Inter-day $(n=6)$ & \multicolumn{3}{|l}{} \\
1.00 & 1.01 & 0.98 & 101.00 & 1.00 \\
5.00 & 5.02 & 0.81 & 100.40 & 0.40 \\
15.00 & 15.05 & 0.70 & 100.33 & 0.33 \\
25.00 & 25.07 & 0.58 & 100.28 & 0.28 \\
40.00 & 40.24 & 0.39 & 100.60 & 0.60 \\
\hline
\end{tabular}

Selectivity

The proposed method was found to be selective for the determination of MD in the presence of various tablet excipients. The recoveries were not affected by the excipients and the excipients blend did not show any absorption in the range of analysis.

\section{Robustness}

Robustness was examined by evaluating the influence of small variation of method variables (Table 3 ) including MBTH, $\mathrm{Fe}(\mathrm{CN})_{6}{ }^{3-}$ and $\mathrm{Na}_{2} \mathrm{CO}_{3}$ volume, measurement time and temperature on the method suitability and sensitivity. The robustness of the method was studied by using five replicates at MD concentration level of $50 \mu \mathrm{g} \mathrm{mL}^{-1}$. The degree of reproducibility of the results obtained as a result of small deliberate variations in the method parameters has proven that the method is robust.

Table 3. Results of robustness study of MD.

\begin{tabular}{|c|c|c|}
\hline \multicolumn{2}{|l|}{ Parameter variation } & \multirow{2}{*}{\begin{tabular}{|l|} 
Recovery\% \pm SD \\
$101.02 \pm 0.19$ \\
\end{tabular}} \\
\hline No Change & - & \\
\hline \multirow{2}{*}{\begin{tabular}{|l}
$\begin{array}{l}\text { Change in } \\
\text { volume }\end{array}$ \\
\end{tabular}} & $0.5 \mathrm{~mL}$ & $98.89 \pm 0.21$ \\
\hline & $0.7 \mathrm{~mL}$ & $100.02 \pm 0.16$ \\
\hline \multirow{2}{*}{$\begin{array}{l}\text { Change in } \mathrm{K}_{3}\left[\mathrm{Fe}(\mathrm{CN})_{6}\right] 0.01 \mathrm{M} \\
\text { volume }\end{array}$} & $1.9 \mathrm{~mL}$ & $101.04 \pm 0.22$ \\
\hline & $2.1 \mathrm{~mL}$ & $100.98 \pm 0.24$ \\
\hline \multirow{2}{*}{$\begin{array}{lllll}\begin{array}{l}\text { Change in } \\
\text { volume }\end{array} & \mathrm{Na}_{2} \mathrm{CO}_{3} & 0.1 & \mathrm{M} \\
& & & \\
\end{array}$} & $0.1 \mathrm{~mL}$ & $98.76 \pm 0.17$ \\
\hline & $0.3 \mathrm{~mL}$ & $100.01 \pm 0.18$ \\
\hline \multirow[t]{2}{*}{ Change in measurement time } & $5.0 \mathrm{~min}$ & $100.92 \pm 0.11$ \\
\hline & $15 \mathrm{~min}$ & $101.08 \pm 0.14$ \\
\hline \multirow[t]{2}{*}{ Change in temperature } & $20^{\circ} \mathrm{C}$ & $100.94 \pm 0.15$ \\
\hline & $30^{\circ} \mathrm{C}$ & $101.09 \pm 0.12$ \\
\hline
\end{tabular}

\section{Application to the pharmaceutical dosage forms}

The proposed method was successfully applied for the determination of MD in tablet commercial formulations. The results given in Table 4 compared favorably with the 
official method [2], at $95 \%$ confidence level, confirming the applicability of the proposed method for the determination of MD in pharmaceutical dosage forms (tablets). The results obtained were compared statistically [52]; the data of $t$ and $F$ ratios show no significant differences between the results of the proposed and the official methods, at a $95 \%$ confidence level. The RSD values obtained for the samples are between 0.6 and $0.8 \%$, as shown in Table 4 , indicating good precision of the method. The ingredients in the tablets such as starch, lactose, glucose, sodium chloride and titanium dioxide do not interfere with the assay procedures. Therefore, the spectrophotometric method for determination of MD in pharmaceutical formulations reported in this paper is precise, accurate, and suitable for use in routine analysis.

Table 4. Determination of MD in tablets by the proposed and pharmacopoeial methods.

\begin{tabular}{|c|c|c|c|}
\hline \multirow[b]{2}{*}{ Sample } & \multirow{2}{*}{$\begin{array}{l}\text { Label value } \\
\text { (mg/tablet) }\end{array}$} & \multicolumn{2}{|c|}{ Amount $(\mathrm{mg})^{\mathrm{a}} \pm \mathrm{SD}$} \\
\hline & & Proposed method & \begin{tabular}{|l|} 
Oficial \\
method [2]
\end{tabular} \\
\hline Aldomet & 250 & $\begin{array}{l}254.83 \pm 1.58 \\
t=2.13 \\
F=1.59\end{array}$ & $\begin{array}{l}251.54 \pm 1.38 \\
t=1.69\end{array}$ \\
\hline Dopegyt & 250 & $\begin{array}{l}252.22 \pm 1.87 \\
t=1.96 \\
F=1.44\end{array}$ & $\begin{array}{l}249.78 \pm 0.19 \\
t=1.63\end{array}$ \\
\hline
\end{tabular}

${ }^{a}$ Five independent analyses. At $95 \%$ confidence level t-critical is 2.776 and $\mathrm{F}$-value is 6.26 .

\section{Conclusion}

In the present study, an oxidative coupling reaction for the colorimetric determination of methyldopa in commercial pharmaceutical preparations is described. Proposed method makes use of simple reagents, which an ordinary analytical laboratory can afford. The sample recoveries from all formulations were in good agreement with their respective label claims, which suggested non-interference of formulations excipients in the estimation. Method is highly sensitive to permit determination even down to $0.303 \mu \mathrm{g}$ $\mathrm{mL}^{-1}$. This method is simple, rapid, precise, accurate and not time-consuming technique such as GC, HPLC and etc. Therefore, this approach could be considered for the analysis of methyldopa in bulk and tablet dosage form.

\section{Conflict of interest}

The author declares no conflicts of interest.

\section{References}

1. Hoffman BB. Catecholamines, sympathomimetic drugs, and adrenergic receptor antagonists. In: Hardman JG, Limbird LE, Molinoff PB, Ruddon RW, Gilman AG. (editors). Goodman \& Gilman's the pharmacological basis of therapeutics. New York, USA: Mac Graw-Hill, 2005, pp.163-165.
2. The United States Pharmacopoeia, $24^{\text {th }}$ ed.; The United States Pharmacopoeial Convention. Rockville, Maryland, USA, 2000.

3. Amin D. Titrimetric determination of catecholamines and related compounds via bromine oxidation and substitution. Analyst 1986; 111(2): 255-257.

4. Salem FB. Titrimetric and spectrophotometric determination of catecholamines. Anal. Lett. 1993; 26(9): 1959-1966.

5. Antunes RS, Thomaz DV, Garcia LF, de Souza Gil E, Somerset VS et al. Determination of methyldopa and paracetamol in pharmaceutical samples by a low cost genipa americana L. polyphenol oxidase based biosensor. Advanced Pharmaceutical Bulletin 2019; 9(3): 416-422.

6. Zaimbashi R, Beitollahi H, Torkzadeh-Mahani M. Simultaneous electrochemical sensing of methyldopa and hydrochlorothiazide using a novel $\mathrm{ZNO} / \mathrm{AL}_{2} \mathrm{O}_{3}$ nanocomposite modified screen printed electrode. Anal. Bioanal. Electrochem. 2017; 9(8): 1008-1020.

7. Baytak AK, Duzmen S, Teker T, Aslanoglu M. A novel modified electrode based on terbium oxide and carbon nanotubes for the simultaneous determination of methyldopa and paracetamol. Anal. Meth. 2016; 8(23): 4711-4719.

8. Gholivand MB, Amiri M. Highly sensitive and selective determination methyldopa in the presence of ascorbic acid using OPPy/TY/Au modified electrode. J. Electroanal. Chem. 2013; 694: 56-60.

9. Afsaneh L, Sanati, Faridbod F. Electrochemical determination of methyldopa by graphene quantum dot/1-butyl-3-methylimidazolium hexafluoro phosphate nanocomposite electrode. Int. J. Electrochem. Sci. 2017; 12: 7997-8005.

10. Badawy SS, Issa YM, Tag-Eldin AS. Potentiometric determination of L-dopa, carbidopa, methyldopa and aspartame using a new trinitrobenzenesulfonateselective electrode. Electroanalysis (N.Y.), 1996; 8(11): 1060-1064.

11. Athanasiou-Malaki EM, Koupparis MA. Indirect potentiometric determination of $\alpha$-amino-acids with a copper-selective electrode and determination of dopa and methyldopa in pharmaceutical preparations. Anal. Chim. Acta 1984; 161: 349-353.

12. He SH, Li CY, Tian KJ. Study on the chemiluminescence determination of methyldopa with ferricyanide and dichlorofluorescein. Fenxi Kexue Xuebao 2006; 22(6): 707-709.

13. Chaichi MJ, Khajvand T, Mehrzad J, Asghari S, Qandalee M. Indirect chemiluminescence-based determination of catecholamines in pharmaceutical formulations by furandicarboxylate derivative as a novel blue fluorescer in peroxyoxalate- $\mathrm{H}_{2} \mathrm{O}_{2}$ System. Anal. Sci. 2013; 29(8): 815-821.

14. Garrido EM, Lima JL, Delerue-Matos C. Flow injection amperometric determination of L-dopa, epinephrine or dopamine in pharmaceutical preparations. J. Pharm. Biomed. Anal. 1997; 15(6): 845-849.

15. Wang C, Wang Z, Han DD, Hu YX, Zhao J et al. Simultaneous determination of levodopa and 
methyldopa in human serum by capillary electrophoresis. Sepu 2006; 24(4): 389-391.

16. Zecevic M, Zivanovic L, Agatonovic-Kustrin S, Minic D. The use of a response surface methodology on HPLC analysis of methyldopa, amiloride and hydrochlorothiazide in tablets. J. Pharm. Biomed. Anal. 2001; 24(5-6): 1019-1025.

17. Li SF,Wu HL, Yu YJ, Li YN, Nie JF et al. Quantitative analysis of levodopa, carbidopa and methyldopa in human plasma samples using HPLC-DAD combined with second-order calibration based on alternating trilinear decomposition algorithm. Talanta 2010; 81: 805-812.

18. Bahrami G, Kiani A, Mirzaeei S. A rapid high performance liquid chromatographic determination of methyldopa in human serum with fluorescence detection and alumina extraction: Application to a bioequivalence study. J. Chromatogr. B 2006; 832(2): 197-201.

19. Karimi M, Carl JL, Loftin S, Perlmutter JS. Modified high-performance liquid chromatography with electrochemical detection method for plasma measurment of levodopa, 3-O-methyldopa, dopamine, carbidopa, and 3,4-dihydroxyphenyl acetic acid. J. Chromatogr. B 2006, 836(1-2), 120-123.

20. Oliveira CH, Barrientos-Astigarraga RE, Sucupira M, Graudenz GS, Muscara MN et al. Quantification of methyldopa in human plasma by high-performance liquid chromatography-electrospray tandem mass spectrometry. Application to a bioequivalence study. J. Chromatogr. B 2002; 768(2): 341-348.

21. Talebpour Z, Haghgoo S, Shamsipur M. Proton nuclear magnetic resonance spectroscopy analysis for simultaneous determination of levodopa, carbidopa and methyldopa in human serum and pharmaceutical formulations. Anal. Chim. Acta 2004; 506(1): 97-104.

22. Davidson AG. Difference spectrophotometric assay of 1,2-diphenolic drugs in pharmaceutical formulations. II. Germanium dioxide reagent. J. Pharm. Sci. 1984; 73(11): 1582-1584.

23. Hamzah MJ, Shakir IMA. Flow injection photometric assay for determination of methyl dopa using hydrogel approch as a host for the sodium periodate solution. Int. J. Pharm. Sci. Rev. Res. 2016; 41(1): 247-251.

24. Ribeiro PRS, Gomes Neto JA, Pezza L, Pezza HR. Flow-injection spectrophotometric determination of methyldopa in pharmaceutical formulations. Talanta 2005; 67(1): 240-244.

25. Abood NK, Hassan MJM, Al-Da'amy MA. Determination of phenolic drugs and their formulations via various analytical methods. Res. J. Chem. Envir. 2019; 23(1): 188-199.

26. Abood NK, Hassan MJM, Al-Da'amy MA. Spectrophotometric determination methyldopa and salbutamol by oxidative coupling, cloud point and flow injection in pharmaceutical formulations. Int. J. Drug Deliv. Technol. 2019; 9(2): 182-192.

27. Tabrizi AB, Bahrami F, Badrouj H. A very Simple and sensitive spectrofluorimetric method based on the oxidation with cerium (IV) for the determination of four different drugs in their pharmaceutical formulations. Pharm. Sci. 2017; 23: 50-58.

28. Salem FB. Spectrophotometric and fluorimetric determination of catecholamines. Anal. Lett. 1993; 26(2): 281-294.

29. Kaushik RD, Yadav R, Sushma, Manila, Singh J. Development and validation of kineticspectrophotometric method for determination of methyldopa in aqueous formulations and tablets. Der Pharma Chemica 2014; 6(4): 102-108.

30. Tubino M, Batista DCDV, Rodrigues JAR. Kinetic method for the determination of $\alpha$-methyldopa in pharmaceutical preparations: analytical procedure and reaction mechanism considerations. Anal. Lett. 2006; 39(1-3): 327-339.

31. Andrabi SMA, Aziz S, Najam R. Kinetic spectrophotometric determination of an important pharmaceutical compound, $\alpha$-Methyldopa. J. Indian Chem. Soci. 2012; 89(2): 247-251.

32. Zakhari NA, Salem FB, Rizk MS. Spectrophotometric determination of catecholamines using chloranilic acid. Farmaco, Edizione Pratica 1987; 42(4): 103-109.

33. Upadhyay K, Asthana A, Tamrakar RK. Extractive spectrophotometric determination of $\square$-methyldopa in bulk dosage and in its formulations. Res. on Chem. Intermediates 2015; 41(8): 5521-5528.

34. Sane RT, Bhounsule GJ, Sawant SV. Colorimetric determination of levodopa and methyldopa from formulations. Indian Drugs 1987; 24(4): 207-209.

35. Emmanuel J, Shetty AR. Estimation of methyldopa and its dosage forms. Indian Drugs 1984; 21(9): 393-394.

36. Issopoulos PB. High-sensitivity spectrophotometric determination of trace amounts of levodopa, carbidopa and methyldopa. Fresenius' J. Anal. Chem. 1990; 336(2): 124-128.

37. Aman T, Khan IU, Aslam N, Ahmad I. Spectrophotometric determination of methyldopa in pure and pharmaceutical preparations. Anal. Lett. 1998; 31(6): 1007-1020.

38. Nagaraja P, Murthy KCS, Rangappa KS, Gowda NMM. Spectrophotometric methods for the determination of certain catecholamine derivatives in pharmaceutical preparations. Talanta 1998; 46(1): 39-44.

39. Nagaraja P, Vasantha RA, Sunitha KR. A sensitive and selective spectrophotometric estimation of catechol derivatives in pharmaceutical preparations Talanta 2001; 55(6): 1039-1046.

40. Afkhami A, Khatami HA. Determination of some catecholamines based on their reaction with periodate. Zhurnal Analiticheskoi Khimii (Russian J. Anal. Chem.) 2003; 58(2): 157-160.

41. Nagaralli B.S., Seetharamappa J., Melwanki M.B., Ramesh K.C., Keshavayya J., Spectrophotometric investigations of the assay of physiologically active catecholamines in pharmaceutical formulations, $\mathrm{J}$. AOAC Int. 2002, 85(6), 1288-1292.

42. Nagaraja P, Vasantha RA, Sunitha KR. A new sensitive and selective spectrophotometric method for the determination of catechol derivatives and its 
pharmaceutical preparations. J. Pharm. Biomed. Anal. 2001; 25(3-4): 417-424.

43 Helaleh MIH, Rahman N, Abu-Nameh ESM. Use of cerium(IV) nitrate in the spectrophotometric determination of levodopa and methyldopa in the pure form and pharmaceutical preparations. Anal. Sci. 1997; 13(6): 1007-1010.

44. Al Samarrai KF, Al Samarrai ET, Al Samarrai BA. Spectrophotometric determination of methyldopa in pharmaceutical preparations via ion pair formation. Int. J. Res. Pharm. Sci. 2019; 10(2): 1367-1371.

45. da Silva Ribeiro PR, Duarte RM. Development and validation of a simple spectrophotometric method for the determination of methyldopa in both bulk and marketed dosage formulations. Braz. J. Pharm. Sci. 2014; 50(3): 573-582.

46. Matos OR, da Silva FC, da Silva Ribeiro PR. A new, simple and sensitive analytical method for determination of methyldopa in pharmaceutical formulations using the 2,2-diphenyil-picrylhydrazyl. Latin Amer. J. Pharm. 2012; 31(2): 190-194.

47. Gadkariem EA,, Ibrahim KEE, Kamil NAA, Haga MEM, El-Obeid HA. A new spectrophotometric method for the determination of methyldopa. Saudi Pharm. J. 2009; 17: 289- 293.

48. Basyoni Salem F. Spectrophotometric determination of catecholamines. J. Pharm. Belgique 1985; 40(3): 185 190.

49. Rao GR, Raghuveer S, Khadgapathi P. Spectrophotometric determination of methyldopa and its dosage forms using 3-methylbenzothiazolin-2-one hydrazone hydrochloride. Indian Drugs 1985; 22(11): 597-599.

50. Rose J. Advanced physico-chemical experiments, Pittman, London, p. 67, 1964.

51. ICH, Q2 (R1). Validation of analytical procedures: text and methodology, Int. Conf. harm. Geneva; 2005.

52. Miller JN, Miller JC. Statistics and Chemometrics for Analytical Chemistry. London, UK: Chapman \& Hall/CRC, 2005.

53. Long GL, Winefordner JD. Limit of detection. A closer look at the IUPAC definition. Anal. Chem. 1983; 55(7): 712A-721A.

54. Ashour S, Bayram R. Sensitive extractional colorimetric analysis of fexofenadine hydrochloride and irbesartan bases through acid-dye complexation using naphthol blue black in pure form and pharmaceuticals. Modern Chem. 2017; 5(6): 93-100.

55. Martin AN, Swarbrick J, Cammarata A. Physical Pharmacy. Lee and Febiger (editors). Philadelphia, USA: 1983, pp. 344-346. 